\title{
Az uzsorahitelezés nagyságrendi és területi becslése*
}

\author{
El-Meouch Nedim Márton - Fellner Zita - Marosi Anna-Szabó Beáta - Urbán Ákos
}

A pénzügyi mélyüléssel párhuzamosan egyre nagyobb figyelmet kap a lakosság azon szegmense, amely nem vesz részt a formális pénzügyi közvetitésben. E háztartások egy része jellemzően rossz jövedelmi helyzettel rendelkezik, így alacsony hitelképességük miatt hitelkeresletük kielégítetlen marad. Tanulmányunkban a hazai szakirodalomban első alkalommal - az uzsorahitelezés elterjedtségének nagyságrendi becslésére teszünk kísérletet. A sérülékeny, így potenciálisan érintett háztartások nagyságrendjének meghatározásához az Eurostat Survey on Income and Living Conditions felmérésére adott hazai válaszokat használtuk fel. Eredményeink alapján 3-13 százalék közé becsüljük azon hazai háztartások arányát, amelyek pénzügyi és lakhatási helyzetükből adódóan olyan mértékben sérülékenyek, hogy ki lehetnek téve - legalább az eseti - uzsorahitelezés kockázatának. Azon területek azonositásához pedig, amelyekben feltételezhetöen elterjedt a helyi közösséget átszövő uzsorahitelezés, a gazdasági-lakhatási szempontból elmaradott települések és az alacsony (formális) hitelpenetrációjú járások metszetét vettük alapul a Központi Statisztikai Hivatal és a Magyar Nemzeti Bank aggregált adatai alapján. Az uzsorahitelezéssel leginkább érintett területek Borsod-Abaúj-Zemplén, SzabolcsSzatmár-Bereg és Hajdú-Bihar megye országhatárhoz közeli települései lehetnek, amely eredményünket a rendelkezésre álló hivatalos, uzsora-büncselekményekre vonatkozó statisztikák regionális eloszlása is alátámasztja.

Journal of Economic Literature (JEL) kódok: D14, E26, E51, O17, R20

Kulcsszavak: eladósodás, uzsora, hitelkereslet, pénzügyi sérülékenység

\section{Bevezetés}

A világgazdasági válságot követően a hazai háztartási szektor hitelfelvételei 2012ben érték el mélypontjukat, ezt követően viszont egyre bővülő hitelkibocsátásról beszélhetünk, ami mind a lakáshiteleket, mind a fogyasztási hiteleket érintette.

\footnotetext{
* A jelen kiadványban megjelenő írások a szerzők nézeteit tartalmazzák, ami nem feltétlenül egyezik a Magyar Nemzeti Bank hivatalos álláspontjával.

El-Meouch Nedim Márton a Magyar Nemzeti Bank elemzője.E-mail: elmeouchn@mnb.hu Fellner Zita a Magyar Nemzeti Bank közgazdasági elemzője. E-mail: fellnerz@mnb.hu Marosi Anna a Magyar Nemzeti Bank elemzője.E-mail: marosia@mnb.hu Szabó Beáta a Magyar Nemzeti Bank elemzője. E-mail: szabobea@mnb.hu Urbán Ákos a tanulmány írásakor a Magyar Nemzeti Bank elemzője volt.E-mail: akosh.urban@gmail.com A magyar nyelvű kézirat első változata 2019. december 16-án érkezett szerkesztőségünkbe.
} DOI: http://doi.org/10.25201/HSZ.19.2.107132 
Az új hitelek bővülését azonban a válság előtt felvett hitelek törlesztései sokáig ellensúlyozták, így a nominális hitelállomány a gazdaság méretéhez viszonyítva csak 2018 folyamán kezdett emelkedni. A hitelciklus előrehaladtával, a pénzügyi közvetítés ciklikus mélyülésével egyre fokozottabb figyelem terelődik azokra a lakossági szegmensekre, amelyek egyelőre nem vonódtak be a formális intézményrendszer által nyújtott pénzügyi közvetítésbe (azaz nem veszik igénybe a pénzügyi közvetítőrendszer egyik szolgáltatását sem).

A banki látókörből kieső rétegek jellemzően vagy alacsony jövedelemmel rendelkeznek, vagy egyáltalán nem tudnak igazolható jövedelmet bemutatni, emiatt pedig a jelenleg hatályos makroprudenciális (adósságfék) szabályozás szerint nem számítanak hitelképesnek. ${ }^{1}$ Bevonódásuk hiánya egyrészt hosszú távon a pénzügyi mélyülés korlátját jelenti, másrészt akut szociális problémákat okozhat, lévén sem a felügyelet, sem a fogyasztóvédelem látóterébe nem kerülnek be. $E$ háztartások körében - éppen rosszabb anyagi helyzetük miatt - fokozottan lehet jelen a likviditási célú külső forrásbevonás iránti kereslet, adott esetben informális csatornák igénybevételével. Ennek leggyakoribb hazai előfordulása az uzsorahitel, amely magánszemélytől felvett, a hitelpiaci viszonyokhoz képest jellemzően irreálisan magas kamatozású, rövid futamidejü adósságot jelent.

Mivel az uzsorahitelezés törvényileg tiltott tevékenység, nemzetgazdasági szintű méretének megismerhetősége korlátozott: mind a hitelezők, mind az adósok elhallgatják a statisztikai célú felmérések alkalmával, és a „szerződések” nem kerülnek elérhető módon rögzítésre. ${ }^{2}$ Kutatásunk emiatt a nem banki pénzügyi közvetítésnek potenciálisan kitett lakosság vizsgálatára vonatkozott - a tényleges érintettség volumenének megállapítása leküzdhetetlen módszertani akadályokba ütközött. A nagyságrendi becsléshez az Eurostat Survey on Income and Living Conditions (EUSILC) felmérésére adott hazai válaszokat, a területi lehatároláshoz pedig a Központi Statisztikai Hivatal (KSH) településszintű és a Központi Hitelinformációs Rendszer járási szintű adatait használtuk fel.

A tanulmány a következőképpen épül fel: A 2. fejezetben bemutatjuk azokat az aggregált adatokat, amelyek alapján ma Magyarországon azonosítható egy kielégítetlen hiteligény, amit kiegészítünk az uzsorahitelezésre vonatkozó hazai szakirodalom főbb megállapításaival és a bankrendszerhez való kapcsolódás két jelentős korlátjával, az intézményi bizalom és a szolgáltatásokhoz való hozzáférés hiányával. Ezt követi a kutatáshoz használt adatokat, módszereket és az eredményeket bemutató két fejezet. Először a 3. fejezetben az eseti uzsorahitelezésnek potenciálisan kitett, sérülékeny háztartások nagyságrendjére vonatkozó becslést ismertetjük, majd

\footnotetext{
${ }^{1}$ A hatályos adósságfék-szabályokról lásd az 1. mellékletet.

${ }^{2}$ A megismerés azon módjai is korlátozottak, amelyek antropológiai módszerekkel, terepmunkával közelítik meg a kérdést - sőt, ezen kvalitatív, lokális kutatások esetében kutatásetikai dilemmák is felmerülnek az eredmények közzététele kapcsán (Durst 2017).
} 
a 4. fejezetben a helyi közösséget átszövő, széles körben elterjedt uzsorakölcsönzés területi elhelyezkedésére adunk becslést. Ez utóbbi eredményeket a bűnügyi statisztikákkal validáljuk. Végül pedig összegezzük a fő megállapításokat és a további kutatás lehetőségeit, valamint korlátait.

\section{Háttér - A kielégítetlen hitelkereslet forrásai a hivatalos statisztika és a szakirodalom alapján}

A KSH tájékoztatója szerint (KSH 2017) a 2000-es évekre tehető a szegénység, tágabb értelemben a társadalmi kirekesztődés nemzetközileg standardizált mutatóinak (laekeni indikátorrendszer) kidolgozása. Ebben a folyamatban vált általánossá az a nézet, hogy a jövedelem mellett a kirekesztettség olyan dimenziói, mint az anyagi javakkal való ellátottság vagy a munkaerőpiaci helyzet, alapjaiban meghatározzák az életminőséget. Ezek alapján a szegénység vagy társadalmi kirekesztődés kockázatának kitettek arányát megragadó (AROPE: At Risk of Poverty or Social Exclusion) részindikátorok:

1. relatív jövedelmi szegénységben élők aránya, ${ }^{3}$

2. súlyos anyagi deprivációban (nélkülözésben) élők aránya, ${ }^{4}$

3. nagyon alacsony munkaintenzitású háztartásban élők aránya (munkaszegénység). ${ }^{5}$

A legfrissebb, 2018-ra vonatkozó adatok alapján (KSH 2019) a relatív jövedelmi szegények aránya hazánkban 12 százalék, a súlyos anyagi deprivációban élők aránya 9 százalék, a nagyon alacsony munkaintenzitású háztartások aránya pedig 4 százalék

- mindezek eredőjeként a szegénység vagy a társadalmi kirekesztődés kockázatának kitettek aránya hazánkban 19 százalék (1. ábra).

\footnotetext{
${ }^{3}$ Relatív jövedelmi szegények: a relatív szegénységi küszöb alatti jövedelemmel rendelkezők. Relatív szegénységi küszöb: az adott évben a nemzeti ekvivalens nettó háztartásjövedelem mediánjának 60 százaléka. (2018-ban egyfős háztartás esetén évi 1 millió 120 ezer forint, 2 felnőtt esetén 2 gyermekkel 2 millió 351 ezer forint.)

${ }^{4}$ A következő kilenc tétel közül legalább négy fennállása esetében depriváltként azonosítható a háztartás: 1. képtelen a nem várt kiadásokat fedezni; 2 . nem engedhet meg magának évi egy hét nyaralást az otthonán kívül; 3. nem képes a különféle tartozások törlesztésére; 4. nem engedhet meg magának minden másnap egy hús-, csirke- vagy halételt; 5 . nem képes az otthonát megfelelően fűteni. A háztartás anyagi okokból kénytelen lemondani 6. a mosógépről, 7. a színes televízióról, 8. a telefonról, 9. a személyes használatú autóról.

${ }^{5}$ Nagyon alacsony munkaintenzitás: a háztartás munkaképes korú tagjai a lehetséges munkaidejük kevesebb mint 20 százalékát töltik munkával.
} 


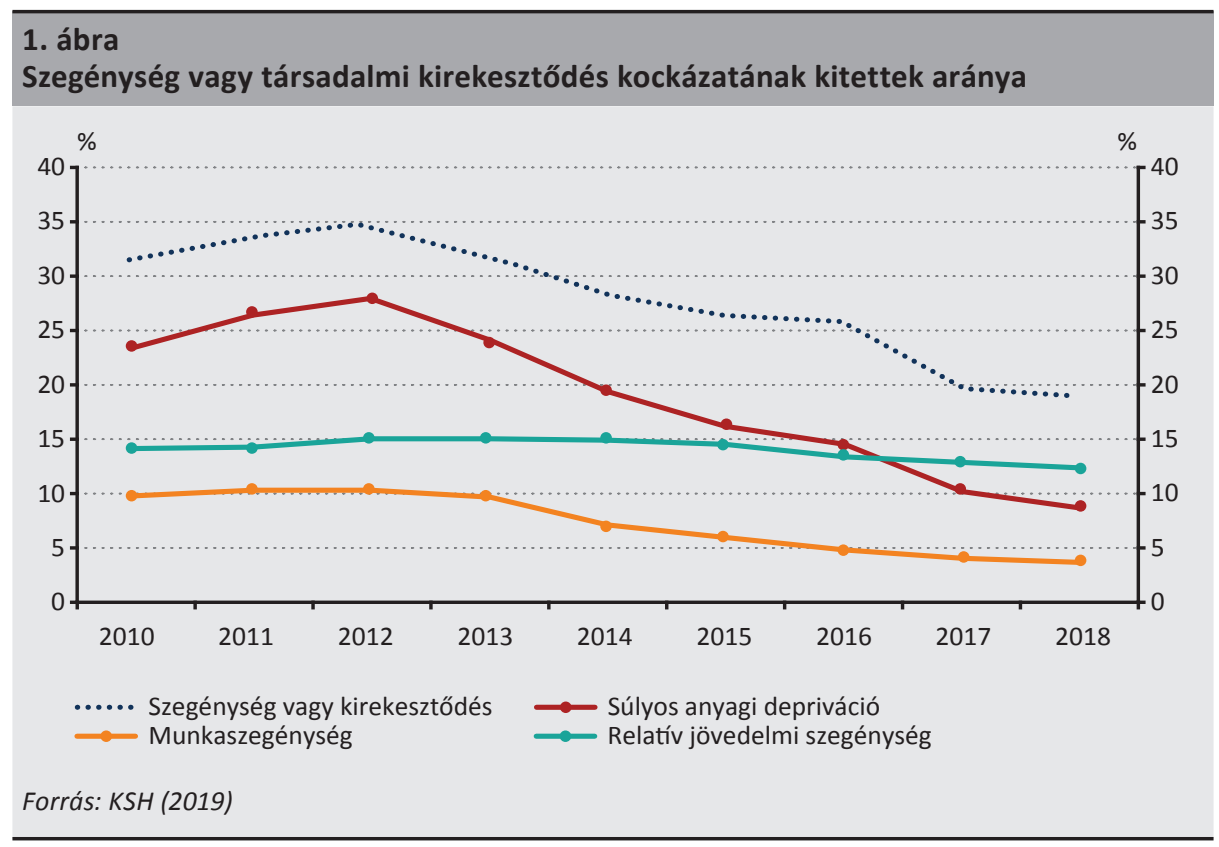

A KSH (2019) szociodemográfiai tényezők mentén megállapítja, hogy a szegénység vagy társadalmi kirekesztődés kockázatának jobban kitettek a fiatalabbak, a legfeljebb alapfokú végzettségúek, a munkanélküliek, a gyermekes (különösen az egyszülős) háztartások, a községben élők, a romák, területi alapon pedig az észak-magyarországi régió lakói.

A súlyos anyagi deprivációban élők - éppen e helyzetük kapcsán - nyilvánvalóan törekednének a nélkülözés megszüntetésére a fogyasztásuk növelésével abban az esetben, ha erre lehetőségük nyílna. Ezzel párhuzamosan a munkaszegénységgel és jövedelmi szegénységgel jellemezhető háztartások közül kerülhetnek ki azok, amelyek hitelfelvételi korláttal szembesülnek, hiszen ebben a szegmensben lehetnek híján a banki hitelfelvételhez elégséges és igazolható jövedelemnek. Ezek azok a rétegek, amelyek a formális pénzügyi intézményrendszer irányába kielégítetlen hitelkeresletet támasztanak, és emiatt az informális, akár illegális személyközi kölcsönzéshez folyamodnak. 


\subsection{A szakirodalom megállapításai}

A szegénységben élők pénzgazdálkodásának mintázatai jelentősen eltérnek a többi társadalmi csoport viselkedésétől, hiszen más eszközökhöz férnek hozzá, ami egyben szükségképpen korlátozottabb lehetőségteret is jelent. Gosztonyi (2018) szerint Frits Bouman $^{6}$ alkotta meg azt a kontextust, amelybe a szegények pénzügyi tranzakciói beágyazódnak, és amelyek szerinte kisléptékűséggel (alacsony jövedelmekhez párosuló alacsony hitelösszegekkel, megtakarításokkal), magas kockázattal és erős kapcsolati függőséggel jellemezhetőek.

Az alacsony jövedelemmel rendelkező háztartások sajátos pénzgazdálkodásuk miatt jellemzően gyengén kapcsolódnak a hagyományos pénzügyi közvetítőrendszerhez: szükség esetén az informális pénzügyi közvetítőkkel lépnek kapcsolatba, amelynek egyik legjelentősebb megjelenési formája az uzsora. Uzsorának azokat az informális alapon nyújtott hiteleket nevezzük, amelyek után aránytalanul nagy kamatot kell megfizetnie az adósnak. A köznyelvben ma is „kamatos pénz” jelzővel illetik, utalva a hitelkonstrukció extrém magas kamattartalmára.

A gazdaságilag elmaradott térségekben a háztartások legfőbb jövedelemforrását a szociális transzferek jelentik. Jellemzően magas a munkanélküliség és az inaktívak száma. A pótlólagos jövedelem, amely az összjövedelmük 22-24 százalékát jelenti, alkalmi munkavállalásból folyik be, mint például mezőgazdasági munkák, építkezések, vas- és fagyűjtések, vagy gyümölcs- és gombaszedés (Messing-Molnár 2011). Az alacsony jövedelemszint miatt ezek a háztartások pénzügyileg rendkívül sérülékenyek, így egy váratlan kiadás veszélyeztetheti a család megélhetését. Ebben a kiszolgáltatott helyzetben kényszerülnek rá az uzsorahitel felvételére. Ezen háztartások egyrészt jellemzően nem rendelkeznek bankkapcsolattal, másrészt a családi és baráti körük is hasonlóan nehéz körülmények között él, így legtöbb esetben alternatív megoldások hiányában döntenek az uzsora felvétele mellett.

A téma külföldi megalapozói, Collins és szerzőtársai (2009) kiemelik, hogy az informális pénzügyi közvetítés több szempont szerint is hátrányosan érinti az ügyfeleket a formális intézményrendszerhez képest. Így például kiszámíthatatlan a piaci likviditás, nincs fogyasztóvédelmi szabályozás, nem veszi figyelembe az üzleti titkokat, hiányzik a szerződéses transzparencia, és ebből fakadóan a piacinál nagyobb (szinte kizárólagos) szerep jut a lokális normáknak és a bizalomnak.

Az uzsorát nyújtó egyének a legtöbb esetben helyi lakosok, akik 1-2 hónapos futamidejü kölcsönöket adnak 50-100 százalékos kamatra. Az ügylet írásban nem kerül rögzítésre, továbbá egy bizonyos összeg (kb. 50 ezer forint) felett agressziót is alkalmaznak a behajtás során. Az uzsorás mindenképp igyekszik behajtani a tartozást,

\footnotetext{
${ }^{6}$ Bouman, F. (1990): Informal Rural Finance - An Aladdin's Lamp of Information. Sociologia Ruralis, 30(2):
} 155-173. 
azonban nem célja az adósság teljes behajtása, fontos számára a függőségi kapcsolat fenntartása is (Béres - Lukács 2008). Az uzsorában érintettek jellemzően nagy családokban (háztartásonként több, mint 4 fő), rossz lakhatási körülmények között, rossz közüzemi ellátottság mellett élnek, és korlátozottan férnek hozzá a közlekedési szolgáltatásokhoz. Alacsony iskolai végzettség és állandósult, tartós munkanélküliség jellemzi óket (Hüse et al. 2008).

Az uzsorát jellemzően egyszeri rendkívüli kiadások indokolják (pl. gyógyszerköltség, lakásfelújítás), de gyakori az az eset is, amikor a pénzt az alapszintű szükségleteik kielégítésére használják fel, ez utóbbi esetben az uzsorahitelt időről-időre újra fel kell venniük. Ezen túlmenően az okok között megjelenik még a szenvedélybetegségek finanszírozása is (alkohol, szerencsejáték). Az uzsorahitelezésben megfigyelhető szezonalitás is, ugyanis télen sokkal több adósság halmozódik fel, amely nyáron jelentősen mérséklődik. Ez a jelenség erős kapcsolatban áll az alkalmi munkavégzési lehetőségekkel és a fútési szezonnal (Gosztonyi 2018).

Magyarországon az uzsorát felvevők nagy többsége roma, de több tanulmány is alátámasztja, hogy ezt nem az etnikai hovatartozás határozza meg, sokkal inkább a hátrányos helyzet (Messing 2006, Béres - Lukács 2008, Messing - Molnár 2011, Gosztonyi 2018). A szegénység tehát determinálja az uzsorát, ezért a megszüntetésére tett törekvéseknek potenciálisan a szegénység felszámolására kell koncentrálniuk.

Az uzsorával potenciálisan érintett lakosság tehát a szegény rétegekből kerül ki, ahol gyakran alakulnak ki akut szükséghelyzetek. Ezekben az esetekben fontos szerep jut a gyorsan hozzáférhető, adott esetben folyamatosan megújítható hitelfelvételnek. Ezzel eljutunk ahhoz a kérdéshez, hogy mi okozza széles társadalmi csoportok kimaradását a pénzügyi közvetítőrendszerből. A jövedelmi korlátok előtt röviden megvizsgálunk két tényezőt, amely a bankkapcsolat hiányát magyarázza: a pénzügyi bevonódás hajlandóságbeli és képességbeli korlátait.

\subsection{A bankkapcsolat hiányának két potenciális összetevője: bizalom és hozzáférés}

Hazánkban a lakosság mintegy 25 százaléka nem rendelkezik bankkapcsolattal, azaz nincs folyószámlája, ${ }^{7}$ így nem tud élni a pénzügyi termékek, a kamatozó megtakarítások és a hitel nyújtotta lehetőségekkel. Emögött több ok is meghúzódhat, amelyeket felbonthatunk hajlandóságbeli (bizalmi) és képességbeli (hozzáférési) tényezőkre.

A bankrendszerbe vetett lakossági bizalom világszerte megsínylette a 2008-as pénzügyi válságot. Ennek ellenére a World Values Survey 2010 és 2014 között lefolytatott, 60 országra kiterjedő kutatása szerint számos országban a lakosság több mint fele bízik a bankokban. Bár ebben a kutatásban Magyarország nem vett részt, markáns régiós különbségek rajzolódnak ki, amelyek indikációt adhatnak a hazai helyzet

\footnotetext{
${ }^{7}$ A Világbank Global Findex Database 2017. évi adata alapján.
} 
nemzetközi elhelyezkedésére. A legnagyobb fokú bizalom a távol-keleti országokat jellemzi, ezt követik az afrikai és közel-keleti államok, majd Dél-Amerika, Ausztrália és az Egyesült Államok, és a sor végén találhatóak a felmérésben részt vevő európai országok (2. ábra). Így hazánk nemzetközi összehasonlításban vélhetően az alacsony bankrendszeri bizalommal jellemezhető országok közé tartozik. Mindazonáltal a Magyar Nemzeti Bank (MNB) egy 2019. évi felmérése szerint a hazai lakosság negyede általában egyáltalán nem bízik a bankokban (3. ábra).

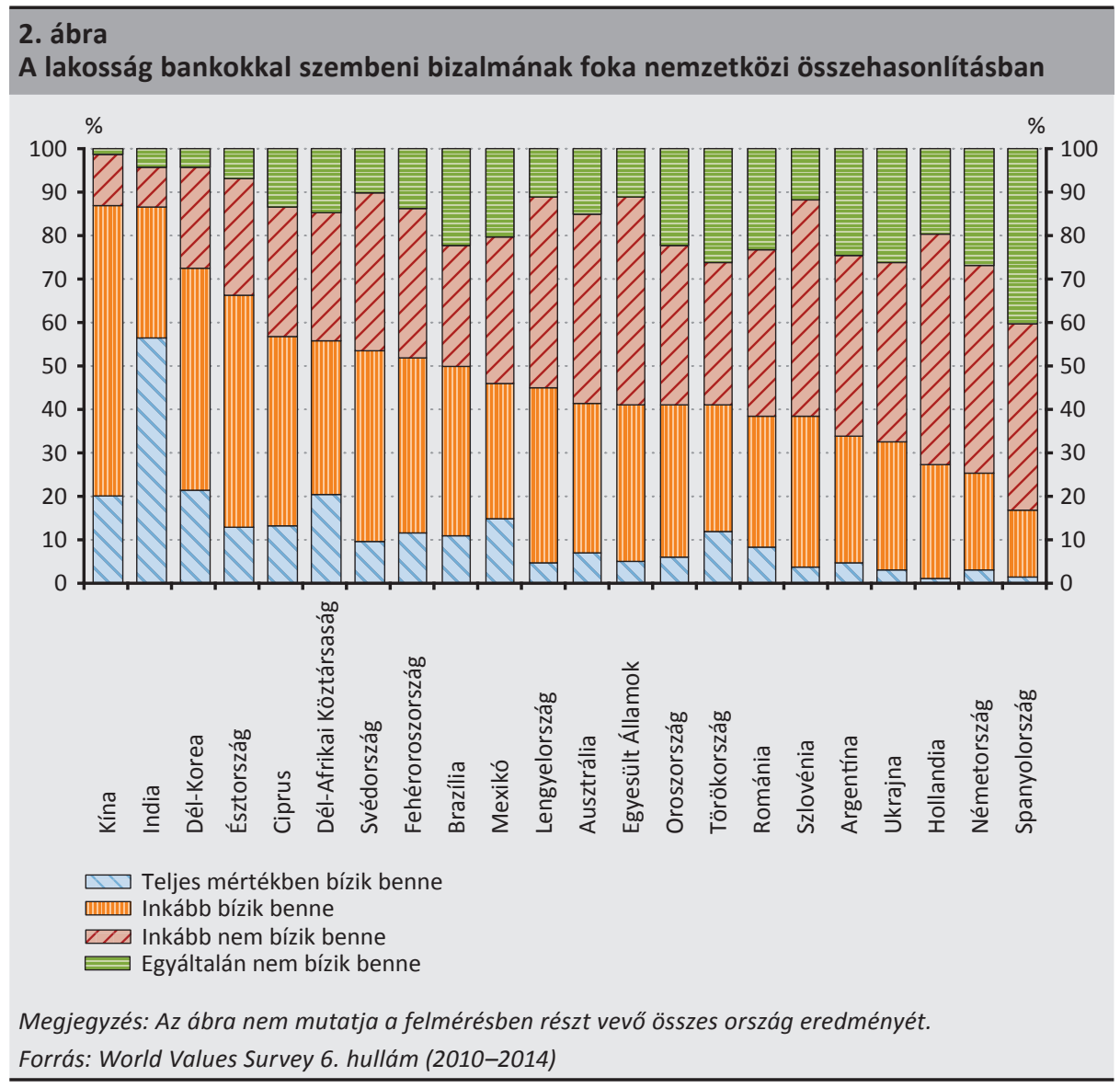




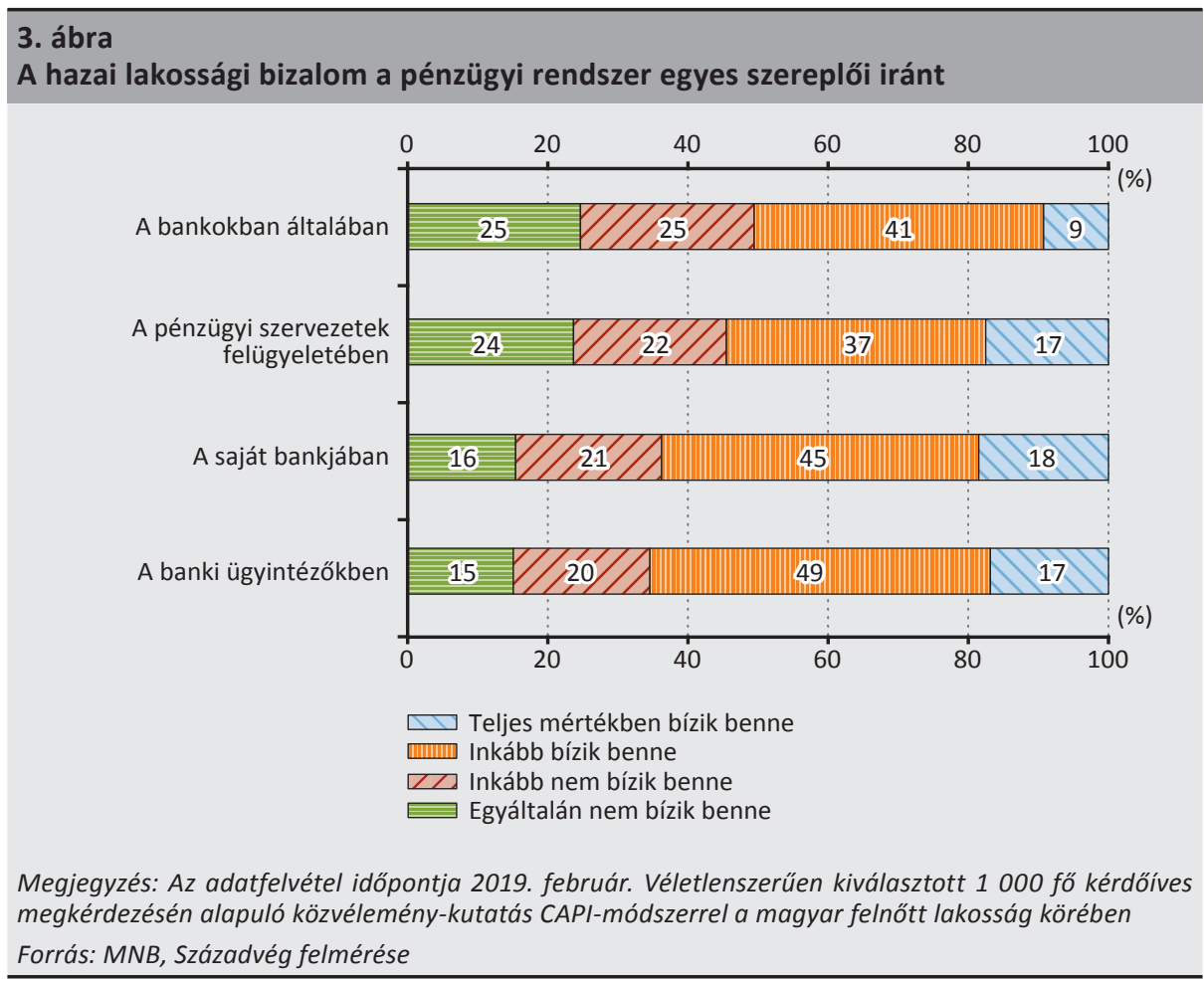

Szintén ezen felmérés alapján tudhatjuk, hogy a bankrendszeri általános intézményi bizalom az idősebbek között, az alapfokú iskolai végzettségúek körében és az észak-alföldi régióban a legalacsonyabb.

A bankrendszerhez való hozzáférés tekintetében érdemes figyelembe venni, hogy jelenleg kevés olyan ATM üzemel, amely készpénz felvételére és befizetésére is alkalmas. Így amennyiben olyan személy szeretne megtakarítás vagy hiteltörlesztés kapcsán egy bank ügyfele lenni, aki nem folyószámlára kapja a jövedelmét, annak az ügyintézés és a rendszeres befizetés a legközelebbi bankfiók felkeresésével érhető el. ${ }^{8}$ Ezért a pénzügyi intézményrendszerhez való hozzáférést azzal érzékeltetjük, hogy van-e egy adott településen legalább egy banknak vagy takarékszövetkezetnek fiókja.

\footnotetext{
${ }^{8}$ Alternatívaként felmerülhet a Magyar Postán nyitott Posta bankszámla is, de ez csak 230 postán intézhetó személyesen. Ugyan a KSH (2018) szerint a lakosság 76 százaléka használ gyakran internetet és ezen belül 54 százalék szokott online bankolni, jelenleg legalább az első hitelfelvételhez személyes jelenlét is szükséges, a teljes mértékben online megoldások többnyire már meglévő ügyfelek esetében érhetők el.
} 
Ez alapján jelentős területi egyenlőtlenségek rajzolódnak ki. Összességében a hazai települések 78 százalékában nem található fiók, de míg Közép-Magyarországon és a Dél-Alföldön szinte mindenhol biztosított az elérés, Észak-Magyarországon, valamint Veszprém, Somogy, Zala és Vas megyékben csak a legnagyobb városokban. Ez azt is jelenti, hogy különösen a nyugat- és dél-dunántúli régióban, de Nógrád és Borsod-Abaúj-Zemplén megyékben is jelentős probléma lehet, hogy miközben a vidéki közlekedési infrastruktúra nem elég rugalmas a nagyobb települések eléréséhez, helyben nincs pénzügyi infrastruktúra kiépítve (4. ábra). A - bankok múködési költségét jelentősen növelő - bankfiókok telepítése helyett ezekben a térségekben a pénzügyi hozzáférés javulását a digitális, készpénzmentes megoldások terjedése mellett a gazdaság fehéredése segíthetné, ami azonban túlmutat jelen tanulmány keretein.

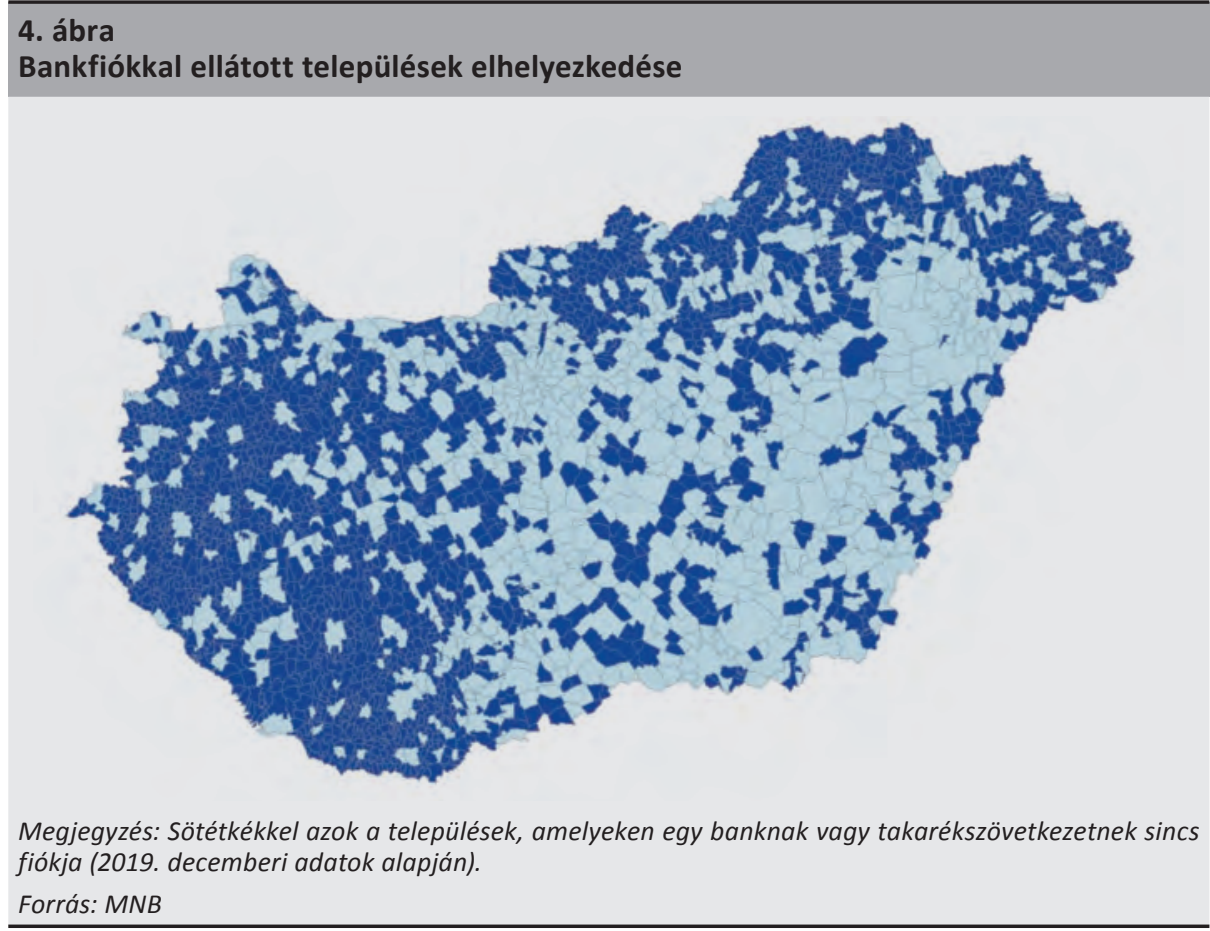

A továbbiakban az uzsorahitelezéssel potenciálisan érintett hazai lakosságra adott nagyságrendi és területi becslésünk eredményeit mutatjuk be. Fontos hangsúlyozni, hogy a nagyságrendi becslés a sérülékenységből fakadóan legalább eseti jelleggel uzsorával potenciálisan érintett háztartások arányára vonatkozik; míg a területi becslés azokra a településekre irányul, ahol vélhetően szélesebb körben is elterjedt lehet az uzsorahitelezés a települések és járások aggregált adatai alapján. Vizsgálatunk 
közvetlen adatforrások híján csak indirekt becslésre terjed ki, ezért a visszamérési lehetőségeink korlátozottak.

\section{Az uzsorával potenciálisan érintett lakosság nagysága - mikroszintű adatok alapján}

Az informális pénzügyi közvetítésnek potenciálisan kitett, pénzügyileg sérülékeny csoportokra vonatkozóan nem állnak rendelkezésre konkrét adatok, így a célcsoport azonosításához az Európai Unió háztartási jövedelem és életkörülmény felmérését (SILC - Survey on Income and Living Conditions) használtuk fel, amely 8142 magyar háztartás részvételével készült. ${ }^{9} A$ felmérés vizsgálatunk szempontjából releváns kérdéseket tartalmaz, ugyanis többek között a bevételek és kiadások mérete és szerkezete, ${ }^{10}$ a relatív anyagi helyzet, az életkörülmények (lakáshelyzet), a pénzügyi helyzet (hitelek megléte), illetve a bankkapcsolat (folyószámla megléte) is szerepel közöttük.

Először azokat a háztartásokat azonosítottuk, amelyek esetében a bevallott kiadások meghaladják a bevallott bevételeket (negativ jövedelmi rés), hiszen esetükben nagy eséllyel léphet fel - elsősorban likviditási - hitelkereslet. A mintában szereplő háztartások 34 százaléka esetében tapasztalható havi deficit ebben az értelemben. Ugyanakkor tekintettel arra, hogy a háztartások valószínűsíthetően felüljelentik a kiadásaikat, viszont aluljelentik a bevételeiket, szükségesnek láttuk további sérülékenységi változók vizsgálatát is.

A sérülékenység meghatározására az intuíció és a szakirodalmi tapasztalatok alapján a felmérésben szereplő változók közül a következő tényezőket választottuk ki:

(1) A háztartás nem képes arra, hogy 70 ezer forintos váratlan kiadást saját forrásaiból fedezzen.

(2) A háztartás egyik tagjának sincs folyószámlája.

(3) A háztartás kétszer vagy többször késett az adatfelvételt megelőző 12 hónapban pénzhiány miatt lakbérrel/közüzemi számla befizetésével/lakáshitel-törlesztőrészlettel.

(4) - (5) A háztartás szubjektív jövedelmi helyzete kedvezőtlen (két változó): 1) a szokásos kiadásokat nagy nehézségek vagy nehézségek árán tudja fedezni, illetve 2) saját jövedelmi helyzetét az alsó három decilisbe helyezi.

${ }^{9}$ 2017-ben felvett, 2016-ra vonatkozó adatok.

${ }^{10} \mathrm{~A}$ bevételi és kiadási oldalra vonatkozóan eltérő volt az időkezelés: a jövedelem a 2016. évi háztartásjövedelmet jelentette, a kiadások pedig „egy átlagos hónapra” vonatkoztak, aminek megítélésében a lekérdezéshez közelebbi hónapok nagyobb súllyal szerepelhettek. 
(6) A háztartás kedvezőtlen lakáskörülmények között él: nincs/közös a mellékhelyiség vagy nincs/közös a zuhany vagy nem tudja elég melegen tartani a lakást vagy nincs a lakásban vezetékes víz.

Az egyes változók alapján vegyes kép rajzolódik ki: a minta 9-42 százaléka tekinthető sérülékenynek (1. táblázat). Az elemzésünk szempontjából kiemelten fontos folyószámlahiány szerint a válaszadók nagy része, 28 százaléka nincs banki látókörben. A pénzhiány miatti fizetéselmaradások fordulnak elő a legkisebb arányban, vélhetően ugyanis a prioritások között elöl helyezkedik el, hogy a háztartásnak ne legyen lakhatással kapcsolatos tartozása. A kiadási nehézség ellenben váratlanul nagy arányú, 42 százalékos gyakoriságú a mintában, de ebben egyfajta túlzottan negatív percepcióra való hajlam is szerepet játszhat.

\begin{tabular}{|c|c|}
\hline \multicolumn{2}{|c|}{$\begin{array}{l}\text { 1. táblázat } \\
\text { Az egyes változók szerint sérülékeny háztartások aránya a mintában }\end{array}$} \\
\hline Sérülékenységi változók & $\begin{array}{c}\text { A sérülékeny háztartások aránya } \\
\text { a teljes mintában (\%) }\end{array}$ \\
\hline $\begin{array}{l}\text { A háztartás kétszer vagy többször késett pénzhiány miatt lakbérrel/ } \\
\text { közüzemi számla befizetésével/lakáshitel-törlesztőrészlettel }\end{array}$ & 8,9 \\
\hline A háztartás kedvezőtlen lakáskörülmények között él & 12,9 \\
\hline $\begin{array}{l}\text { A háztartás saját jövedelmi helyzetét az alsó három decilisbe } \\
\text { helyezi }\end{array}$ & 18,4 \\
\hline A háztartás egyik tagjának sincs folyószámlája & 28,3 \\
\hline $\begin{array}{l}\text { A háztartás nem képes arra, hogy } 70 \text { ezer forintos váratlan kiadást } \\
\text { saját forrásaiból fedezzen }\end{array}$ & 33,9 \\
\hline $\begin{array}{l}\text { A háztartás a szokásos kiadásokat nagy nehézségek vagy } \\
\text { nehézségek árán tudja fedezni }\end{array}$ & 41,9 \\
\hline
\end{tabular}

Meglátásunk szerint ugyanakkor önmagában az egy-egy változó szerinti hátrányos helyzet még nem feltétlenül jelenti a háztartás sérülékenységét. Úgy gondoljuk, hogy a kiszolgáltatottság valószínúsége a sérülékenységi jellemzők számának növekedésével párhuzamosan emelkedik. Ennek megfelelően megnéztük, hogy a mintában szereplő háztartások hogyan oszlanak meg aszerint, hogy hány sérülékenységi változó jellemző rájuk (5. ábra). A háztartások 63 százalékánál jelenik meg legalább az egyik sérülékenységi változó, majd a változók számának növekedésével csökken a részarány. 


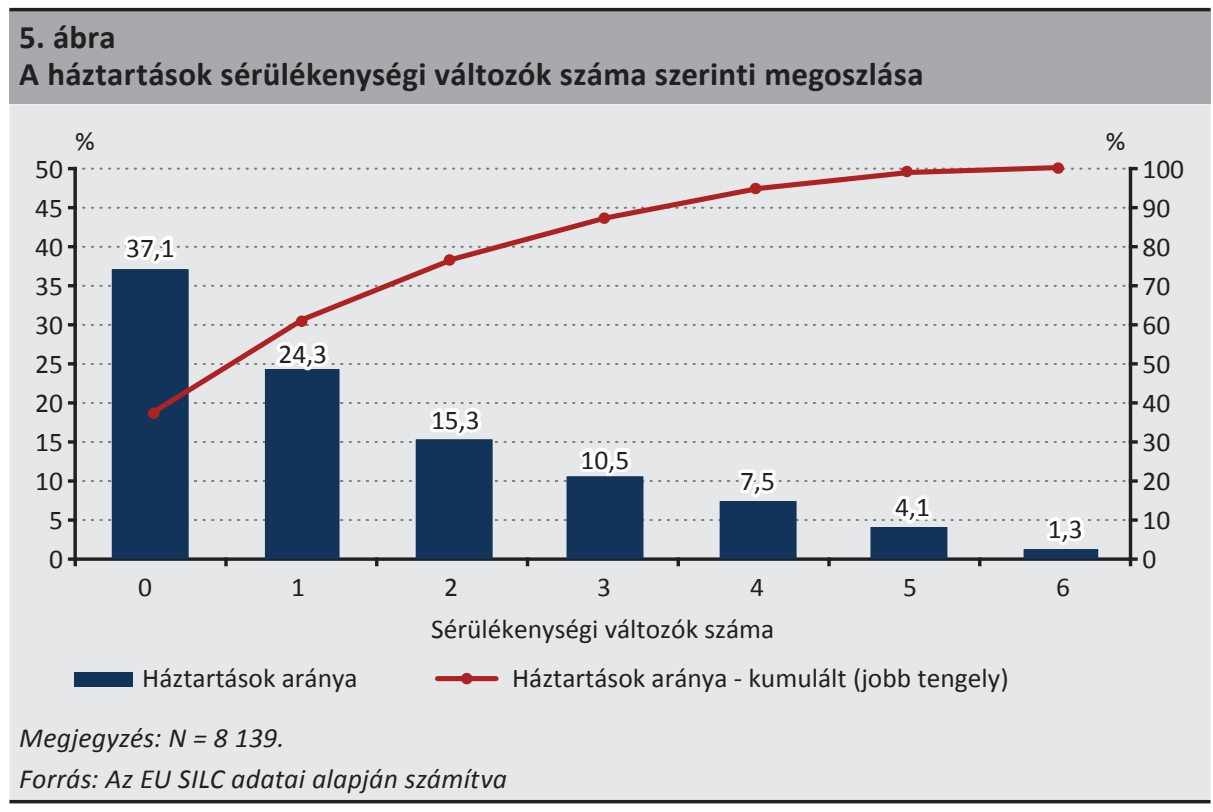

Következő lépésben azt kellett meghatároznunk, hogy a sérülékenységi változók száma szerint mely háztartásokat tekintsük kiszolgáltatottnak, azaz hány sérülékenységi változó együttes fennállása esetén tekintsük az adott háztartást sérülékenynek. Ennek meghatározásához ismét a szakirodalomhoz nyúltunk vissza: megvizsgáltuk a sérülékeny háztartások kiadási szerkezetét, amelyhez a felmérés megfelelő alapot biztosított, hiszen fő kiadási kategóriánként tartalmazott adatokat. A sérülékenységi változók száma szerint csoportosított háztartások esetében az adott kiadási kategória teljes kiadáson belüli arányának mediánját a 2. táblázat mutatja.

\section{2. táblázat}

Háztartási kiadások jellemző részaránya (\%) a sérülékenységi változók száma szerint

\begin{tabular}{c|c|c|c|c|c|c|c|c|c|c}
$\begin{array}{c}\text { Sérülékeny- } \\
\text { ségi válto- } \\
\text { zók száma }\end{array}$ & Élelmiszer & $\begin{array}{c}\text { Alkohol, } \\
\text { cigaretta }\end{array}$ & Ruházat & $\begin{array}{c}\text { Lakás- } \\
\text { fenntartás }\end{array}$ & $\begin{array}{c}\text { Egészség- } \\
\text { ügy }\end{array}$ & Közlekedés & Hírközlés & Kultúra & Oktatás & $\begin{array}{c}\text { Vendég- } \\
\text { látás }\end{array}$ \\
\hline $\mathbf{0}$ & 23,2 & 2,6 & 3,4 & 23,6 & 3,9 & 12,4 & 7,3 & 5,0 & 1,8 & 4,8 \\
\hline $\mathbf{1}$ & 27,2 & 3,3 & 2,6 & 27,0 & 5,4 & 11,2 & 7,0 & 3,9 & 1,5 & 4,9 \\
\hline $\mathbf{2}$ & 28,5 & 3,5 & 2,1 & 29,6 & 5,6 & 9,4 & 6,3 & 3,4 & 1,4 & 5,4 \\
\hline $\mathbf{3}$ & 28,6 & 4,6 & 2,0 & 30,2 & 5,9 & 8,4 & 6,1 & 3,5 & 1,4 & 5,7 \\
\hline $\mathbf{4}$ & 31,0 & 4,4 & 1,8 & 31,0 & 5,3 & 5,2 & 5,8 & 3,6 & 1,2 & 4,8 \\
\hline $\mathbf{5}$ & 33,5 & 6,5 & 1,7 & 31,7 & 5,6 & 4,5 & 4,8 & 3,4 & 0,7 & 4,7 \\
\hline $\mathbf{6}$ & 31,8 & 7,2 & 1,2 & 36,3 & 4,3 & 4,9 & 4,3 & 4,2 & 0,9 & 6,2 \\
\hline
\end{tabular}

Megjegyzés: A sérülékenységi változók száma szerint csoportosított háztartások esetében az adott kiadási kategória teljes kiadáson belüli arányának mediánjait jelenítettük meg.

Forrás: Az EU SILC adatai alapján számítva 
Az eredmények egyfelől megerősítik a szakirodalomban foglaltakat. Látható, hogy minél több szempont szerint sérülékeny egy háztartás, a kiadásainak annál nagyobb részét költi élelmiszerre, alkoholra és dohánytermékre, valamint lakásfenntartásra, míg a ruházatra, és különösen a közlekedésre fordított kiadási részaránya annál alacsonyabb. Másfelől indikációt szolgáltatnak arra is, hogy a sérülékenységi változók száma szerint mely csoportok között húzzuk meg a sérülékenynek tekintett háztartások határát. Az általunk kulcsfontosságúnak tekintett élelmiszer és közlekedés kiadási kategória változóknál látható, hogy - a sérülékenységi változóval nem rendelkező és az egy sérülékenységi változóval rendelkező háztartások közötti különbségeket figyelmen kívül hagyva - a három és négy sérülékenységi változóval jellemezhető háztartások között van a legnagyobb mértékű változás a kiadási részarányokat tekintve. Ennek megfelelően e szempontrendszer szerint azon háztartásokat tekintettük sérülékenynek, amelyek a hat sérülékenységi változónkból legalább bármely négy szerint kiszolgáltatottnak tekinthetők. Ezen háztartások a teljes minta 13 százalékát teszik ki. Konzervatív becslésként továbbá azon háztartásokat is megvizsgáltuk, amelyek ezen felül negatív jövedelmi réssel is rendelkeznek, mivel azt feltételezzük, hogy azok valószínűsíthetően pénzügyileg még inkább hátrányos helyzetben vannak. Ilyen módon definiálva a háztartások 4,3 százaléka sérülékeny.

Tekintettel arra, hogy elemzésünk fókuszában az áll, hogy mely háztartások nincsenek a bankok látókörében, megvizsgáltuk azt is, hogy azon háztartások körében, ahol nem rendelkeznek folyószámlával (ez a teljes minta 28 százaléka) hogyan oszlik meg a sérülékenységi változók száma (6. ábra). Ebben az esetben is a legalább négy sérülékenységi változóval rendelkezőket tekintettük sérülékenynek (melyből értelemszerűen az egyik változó a folyószámlahiány). Azt tapasztaljuk, hogy a folyószámlával nem rendelkezők mintegy 29 százaléka, vagyis a teljes minta 8 százaléka kerül bele az uzsorahitelezésnek legalább eseti szinten potenciálisan kiszolgáltatottak körébe. Alsó korlátként a negatív jövedelmi réssel közös metszetet véve a háztartások 3 százalékát kaptuk. Kiemelendő ugyanakkor, hogy hiába sérülékeny egy háztartás, nem rendelkezünk információval a konkrét pénzügyi megküzdési stratégiájáról (család, barátok, munkáltatói kölcsön, uzsora).

Az uzsorakölcsönzéssel potenciálisan érintett hazai lakosság nagyságrendjére vonatkozóan tehát az Európai Unió háztartási jövedelem és életkörülmény felmérését felhasználva arra az eredményre jutottunk, hogy a hazai lakosság 3-13 százaléka kitett ennek a kockázatnak, ami a magas költségek miatt a szakirodalom alapján könnyen adósságspirálba vezethet. A következőkben - más adatforrásra támaszkodva - a lehetséges érintettség területi becslését mutatjuk be. 


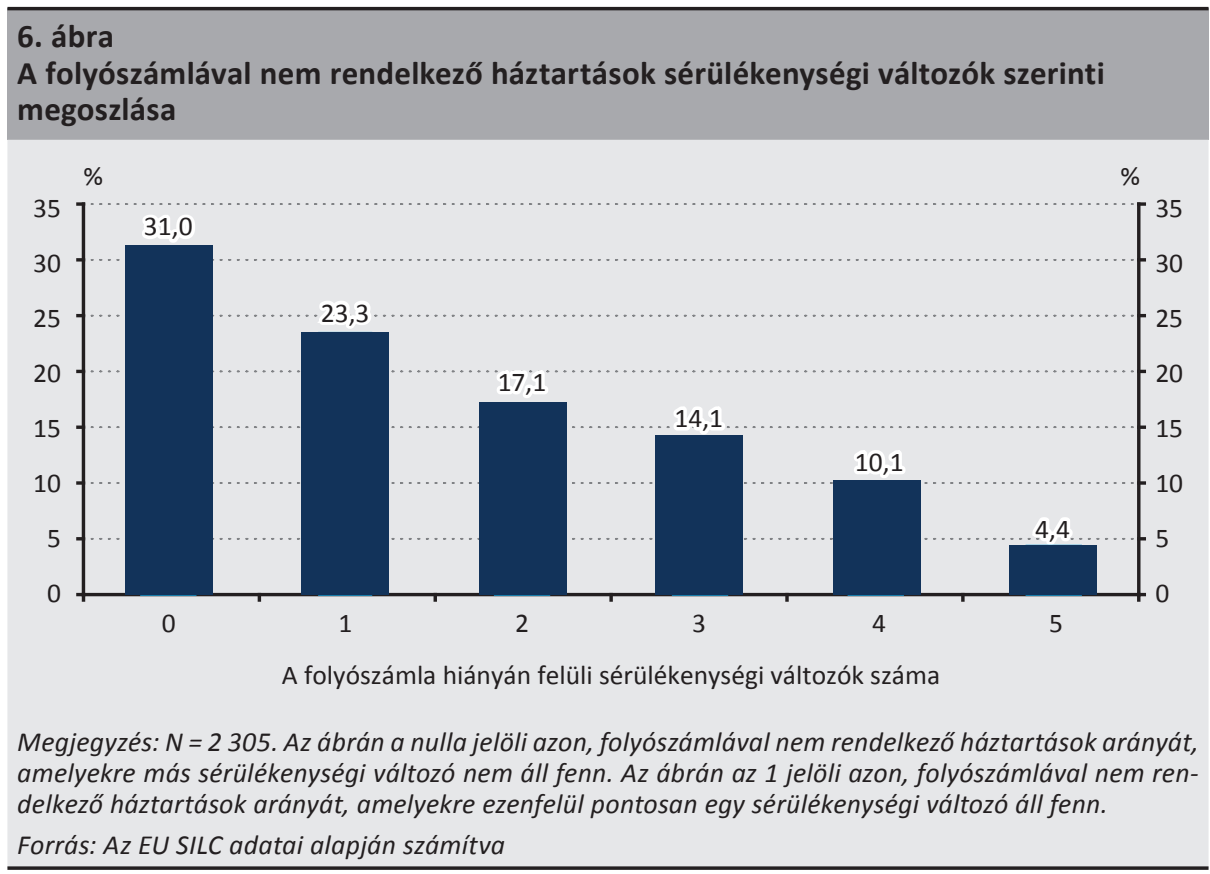

\section{Az uzsorával potenciálisan érintett területek - aggregált adatok alapján}

Magyarországon a lakosság életszínvonala földrajzilag heterogén képet mutat. Ebből kifolyólag az informális hitelezés feltérképezéséhez szükséges feltárni azokat a területeket, ahol a lehetőségek korlátozottak a pénzügyi intézményekkel való kapcsolatfelvételhez. Kutatásunkban az ország legelmaradottabb térségeire fókuszálva vizsgáljuk a bankkapcsolat meglétét, ugyanis ennek hiánya egyik eleme lehet az uzsorahitelezés megjelenésének és széleskörü elterjedésének az adott térségben.

A gazdasági elmaradottság méréséhez négy tényezőt vettünk figyelembe:

- Munkanélküliségi ráta (\%): a munkanélküliek száma a munkanélküliek és a foglalkoztatottak számához viszonyítva.

- Alapfokú iskolai végzettségűek aránya (\%): a legfeljebb alapfokú végzettséggel rendelkezők száma a felnőtt lakossághoz viszonyítva.

- Komfort nélküli lakások aránya (\%): azon lakások aránya, amelyek legalább egy lakószobával és főzőhelyiséggel rendelkeznek, de nem rendelkeznek fürdőszobával és mellékhelyiséggel, a víz- és villanyellátás nem biztosított, továbbá kizárólag egyedi módon füthetők.

• Zsúfoltság (fő/100 szoba): 100 szobára jutó lakók száma a zsúfolt lakhatási körülmények mérésére. 
Ezek az indikátorok a 2011. évi népszámlálás településsoros adatai alapján készültek (7. ábra), így némiképp elavultnak tekinthetők. Ugyanakkor teljeskörüségük, adatminőségük miatt megfelelő forrásai lehetnek a gazdasági elmaradottság mérésének, annál is inkább, mert nem egészen egy évtized alatt valószínúsíthetően kevés település relatív helyzete változott meg jelentős mértékben.

\section{7. ábra}

Az elmaradottság indikátorainak települések szerinti eloszlása
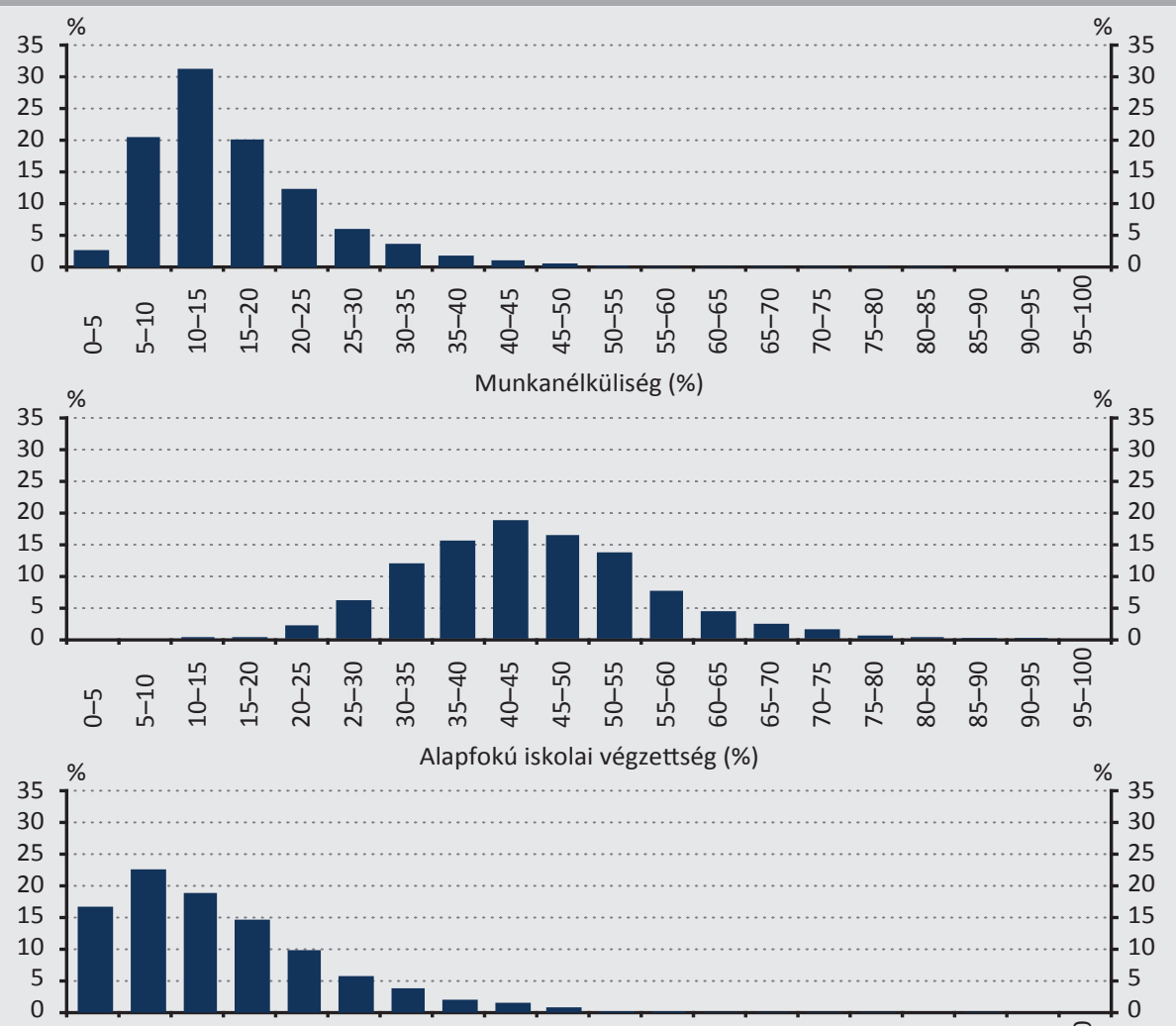

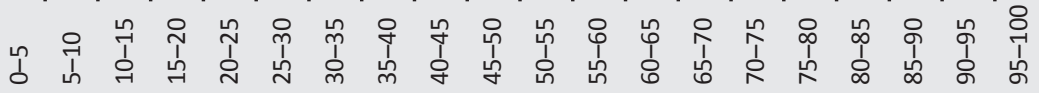

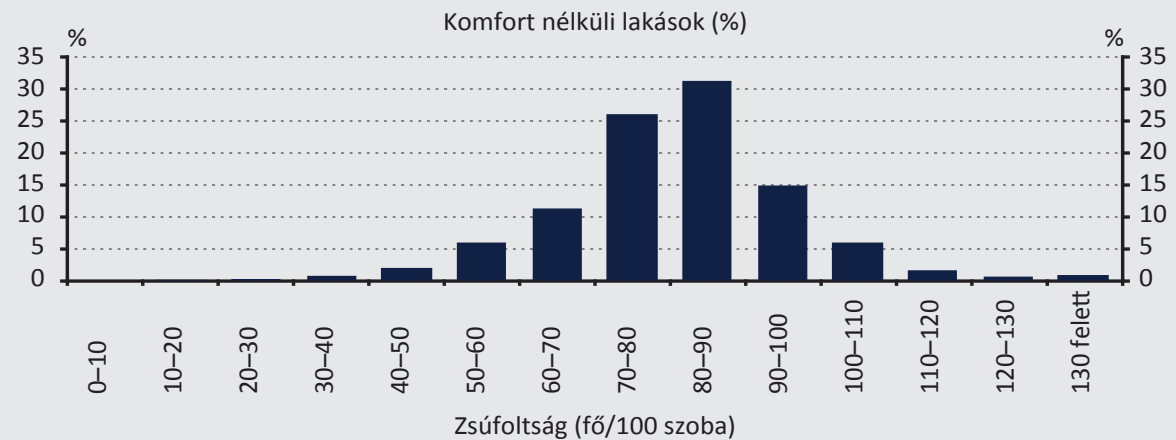

Megjegyzés: A vízszintes tengelyen az adott változó értéksávjai vannak feltüntetve. Forrás: KSH 
A fenti négy indikátort standardizálást követően (melyet a nagyságrendbeli és szóródási eltérések kiszúrése miatt végeztünk el) átlagoltuk, így kaptuk meg a gazdasági-lakhatási elmaradottság településenkénti értékét (8. ábra). Az így kapott mutató egy mértékegység nélküli szám, amely a települések egymáshoz viszonyított fejlettségét hivatott jelezni. A konstruált gazdasági-lakhatási elmaradottsági indexből négy kategóriát képeztünk, amihez a mutató gyakorisági eloszlásában látott, nagyobb mértékű változásokat vettük alapul. Ezzel tulajdonképpen a legfejlettebb és legkevésbé fejlett településeket határoltuk le azon feltételezés alapján, hogy ezen csoportok számosságukban is jól elkülöníthetők a többi településtől. Így azonosítottuk a hazai települések legelmaradottabb 12 százalékát, amelyeken tehát átlagosan a legrosszabb a gazdasági és lakhatási helyzet.

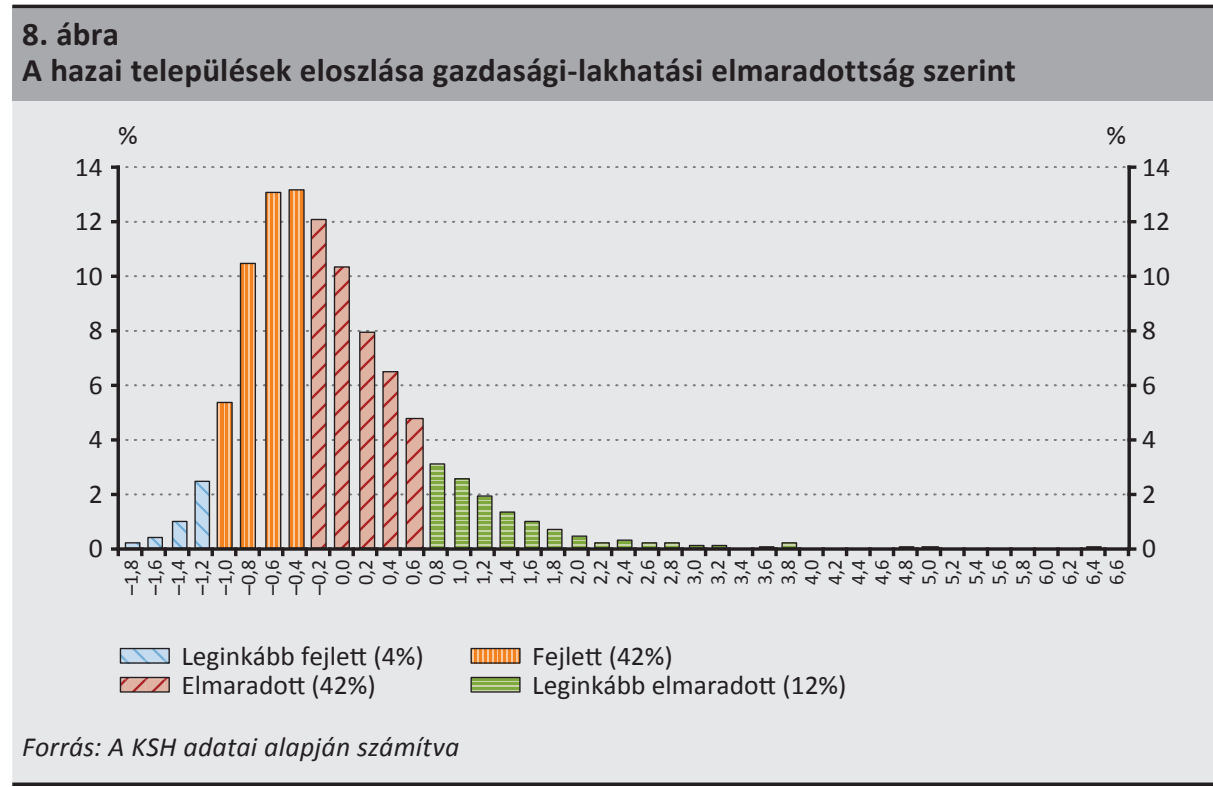

A települések területi elhelyezkedése alapján az látszik, hogy a gazdasági-lakhatási szempontból leginkább elmaradott települések Észak-Magyarországon, HajdúBihar és Jász-Nagykun-Szolnok megyékben, továbbá a Dél-Dunántúlon találhatóak, miközben a nyugat-dunántúli és közép-magyarországi települések többségének a legkedvezőbb a relatív helyzete (9. ábra). A gazdasági-lakhatási elmaradottság mutatószáma alapján a 10 legszegényebb település közül 7 Borsod-Abaúj-Zemplén megyében található, és elsősorban a Cserehát apró települései érintettek az alacsony iskolázottság, foglalkoztatottság és jövedelem okozta nélkülözés problémájában. 


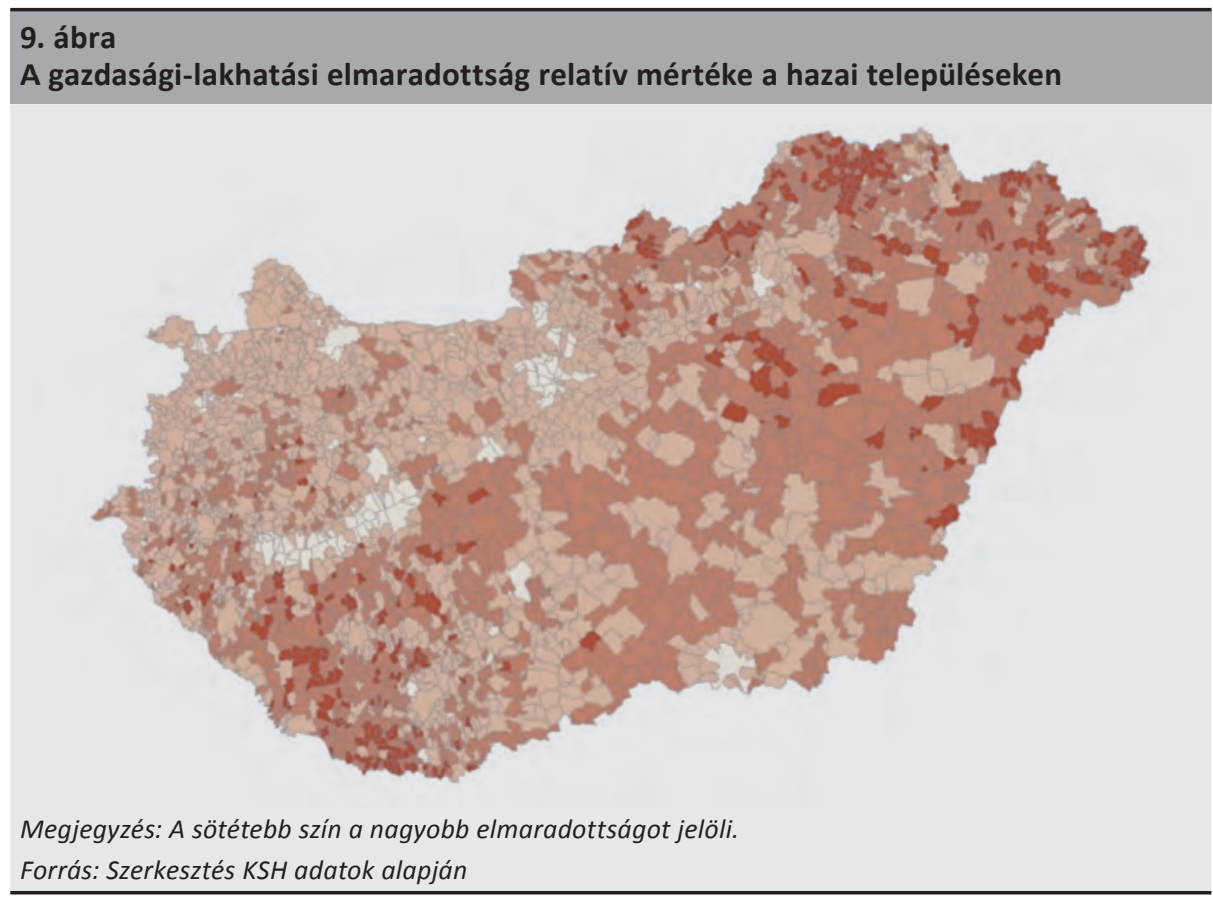

Az uzsorahitelezésnek való kitettség a rossz gazdasági körülmények mellett annak is köszönhető, hogy a térség nincs kellően becsatornázva a banki látókörbe, és emiatt alacsony a „formális” hitelpenetráció. Annak érdekében, hogy ezt is figyelembe vehessük az elemzésben, a Központi Hitelinformációs Rendszer (KHR) adatai alapján megállapítottuk a 2018 végén hitellel rendelkezők arányát a teljes felnőtt korú népességhez viszonyítva járási szinten (ezek az adatok településszinten nem állnak rendelkezésre). Alacsonynak tekintettük a hitelpenetrációt azokban a járásokban, ahol a lakosság kevesebb mint 32 százaléka rendelkezik hitellel (10. ábra). 


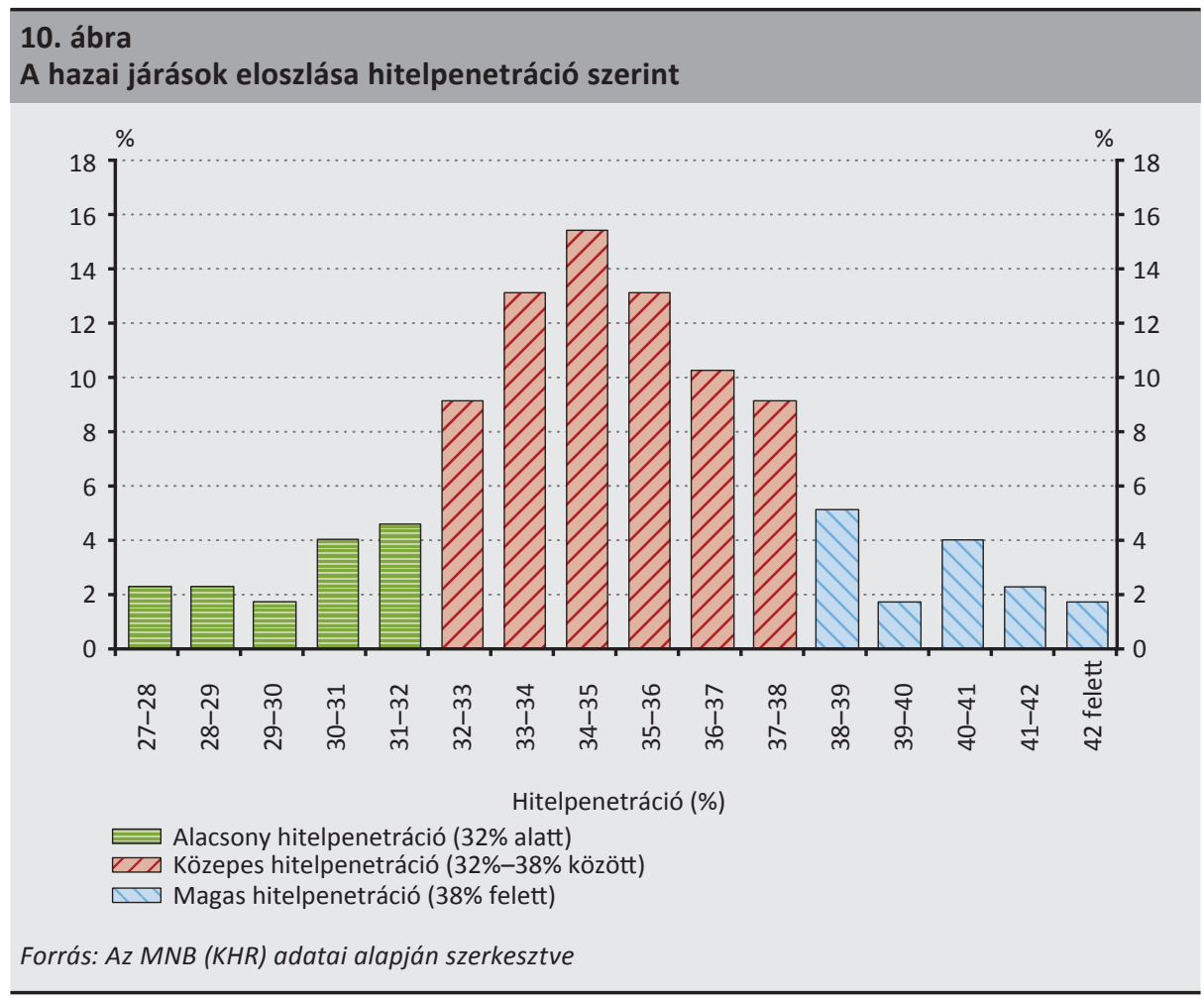

A hitelpenetráció nincs direkt összefüggésben a gazdasági elmaradottsággal: a legelmaradottabb megyék közé tartozó Baranyában találhatók olyan járások, amelyek a legmagasabb hitelpenetrációjú csoportba tartoznak. Megyei összevetésben alacsony hitelpenetráció egyaránt előfordul a legelmaradottabb (Borsod-Abaúj-Zemplén) és a legfejlettebb (Győr-Moson-Sopron) járásokban is (11. ábra). A fejlett és elmaradott járásokra egyaránt jellemző alacsony hitelpenetráció azzal magyarázható, hogy míg a jómódú háztartások kölcsön nélkül is meg tudják valósítani beruházási és fogyasztási céljaikat - illetve a nyugati határ közelében euro jövedelemmel rendelkezők már osztrák bankoktól -, addig a nélkülözésben élők bankkapcsolat, valamint bejelentett munka hiányában nem férnek hozzá a banki hiteltermékekhez (az alacsony hitelpenetrációjú járásokat lásd a 2. mellékletben). 


\section{1. ábra \\ A hitelpenetráció a hazai járásokban}

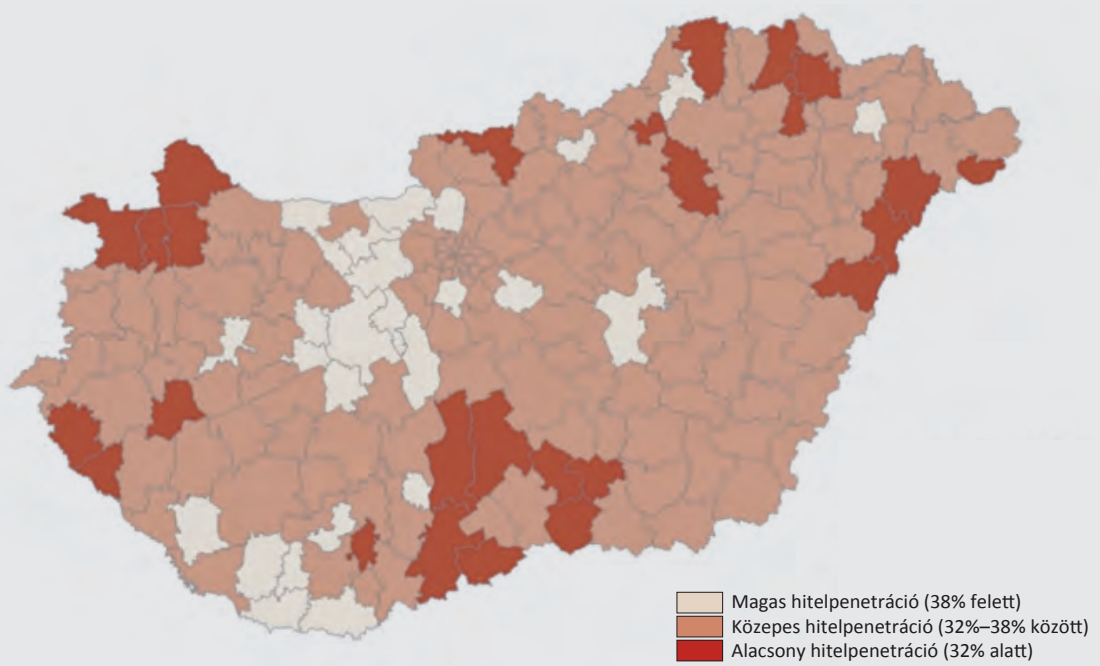

Megjegyzés: A hitelpenetráció a 2018 végén élő hitelszerződések száma a teljes népességhez viszonyítva Forrás: Az MNB (KHR) adatai alapján szerkesztve

Mindezek alapján a gazdasági-lakhatási elmaradottságot és a hitelpenetrációt egyszerre érdemes figyelembe venni, ezek együttesen jelölik ki az uzsorával potenciálisan érintett területeket (12. ábra). E területek tehát azok, amelyekben a gazdasági-lakhatási elmaradottságot mérő index 0,8 feletti, és ezzel párhuzamosan a hitelpenetrációs mutató kisebb, mint 32 százalék. Az így előálló 64 település többsége Borsod-Abaúj-Zemplén megyében található. Ezt követően, kisebb léptékben képviselteti magát Szabolcs-Szatmár-Bereg, Zala és Hajdú-Bihar megye, továbbá egy-egy településsel Baranya, Nógrád és Heves megye. A 64 település közül csak egyben található bankfiók, ami a 2. fejezetben említettek alapján szintén okozója lehet a formális pénzügyi közvetítőrendszerrel való kapcsolat hiányának. Ezen, a lokális közösséget feltételezhetően jobban átszövő, így összességében az uzsorának jobban kitett településeken a teljes népesség 0,43 százaléka él (mintegy 40 ezer fö). ${ }^{11}$

\footnotetext{
${ }^{11}$ Mindez nem azt jelenti, hogy a fejlettebb településeken ne lenne uzsorahitelezés, hiszen nagyvárosokban, akár Budapesten is előfordul, de ezek a települések aggregált fejlettségi mutatóik miatt nem kerülnek be egy ilyen, makromegközelítésű becslés eredményébe.
} 


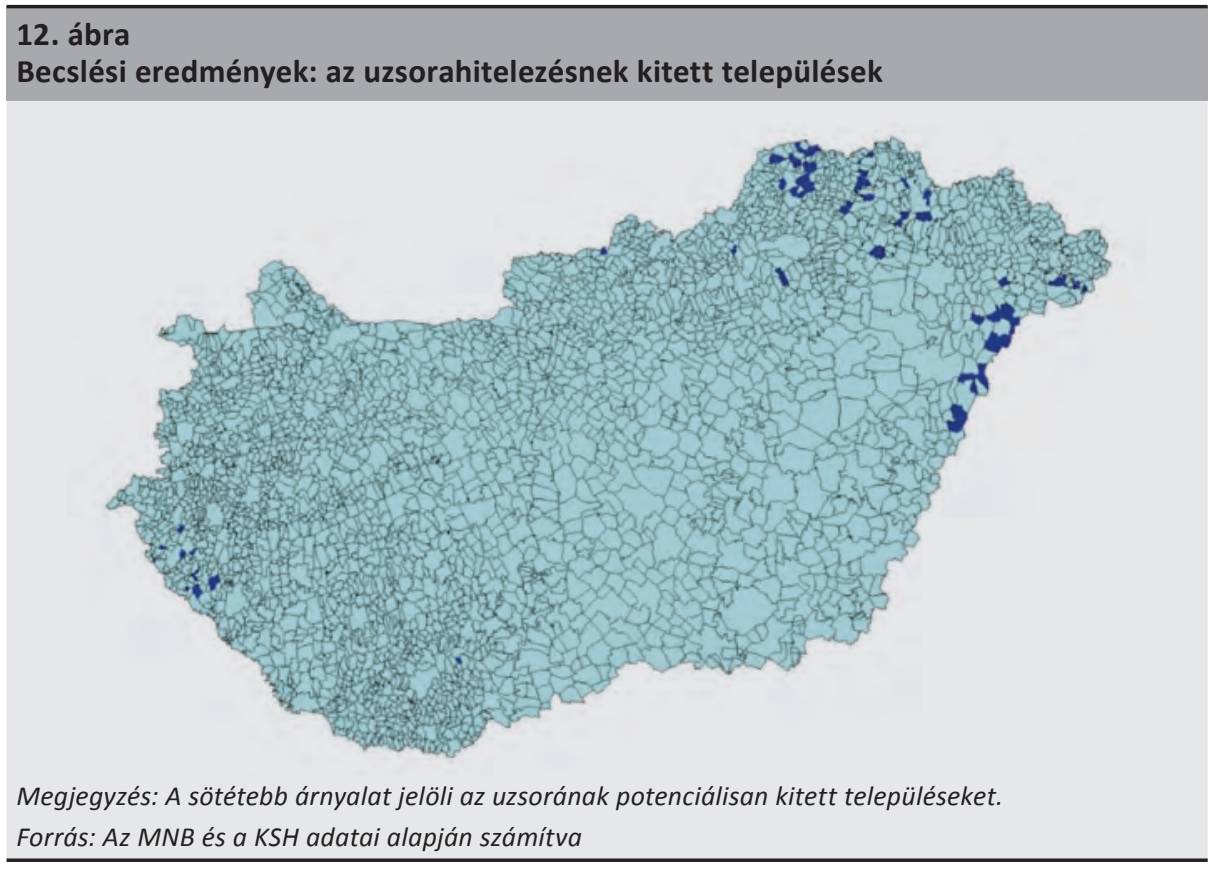

Területi eredményeink validálására közvetlen visszamérési lehetőségeink korlátozottak, mindazonáltal a bűnügyi statisztikák alapján némi indikációt kaphatunk erre nézve.

Az uzsora-bűncselekmény mint büntetőjogi tényállás 2009. március 1-jén lépett hatályba. ${ }^{12} \mathrm{~A}$ - bejelentett - uzsora-büncselekmények száma a rendelkezésre álló adatok szerint 2011-ig meglehetősen limitált volt, ennek azonban nem csupán a jogsértések ténylegesen alacsony előfordulása lehetett az oka (13. ábra). Erre enged következtetni az is, hogy 2011 és 2012 között nagymértékben emelkedett, több mint megháromszorozódott a regisztrált uzsora-bűncselekmények száma, amelyet részben az uzsorával kapcsolatos szabályozás 2011-ben bekövetkezett szigorítása eredményezhetett: az uzsorával összefüggő egyes törvények módosításáról szóló 2011. évi CXXXIV. törvény ugyanis szigorította az uzsora-bűncselekmény büntetését, és tágította a büntetéssel szankcionált cselekmény körét is.

A törvénymódosításig az számított uzsora-büncselekménynek, ha valaki a sértett rászorult helyzetét kihasználva, üzletszerűen, olyan különösen aránytalan mértékű ellenszolgáltatást tartalmazó megállapodást kötött, amelynek teljesítése a sértettet, illetve annak hozzátartozóját súlyos, vagy további nélkülözésnek tette

\footnotetext{
12 Lásd a Büntető Törvénykönyvröl szóló 1978. évi IV. törvény 330/A. paragrafusának 2008. évi CXV. törvény általi módosítását. A Btk. mellett a polgári jog is rendelkezik az uzsoráról: a Polgári Törvénykönyv (Ptk.) már hatálybalépésétől, 1960 májusától uzsorás szerződésnek minősíti, ha a szerződő fél a szerződés megkötésekor a másik fél helyzetének ismeretében és annak kihasználásával feltűnően aránytalan előnyt köt ki.
} 
ki. Az üzletszerüség ebben a megfogalmazásban azt jelentette, hogy az elkövető ugyanolyan, vagy hasonló jellegű bűncselekmények elkövetése révén rendszeres haszonszerzésre törekszik. Ennek a kitételnek köszönhetően ugyanakkor az a személy nem volt büntethető, aki egyetlen alkalommal kötött különösen aránytalan mértékű ellenszolgáltatást tartalmazó megállapodást. A törvénymódosítást követően az elkövető már akkor is büntethetővé vált, ha egyetlen alkalommal követte el a fentieket. További szigorítás, hogy amíg korábban az üzletszerű elkövetést a törvény három évig terjedő szabadságvesztéssel büntette, a módosítást követően akár öt évig terjedő szabadságvesztés is kiszabható. A bűncselekmény felderítését könnyíti emellett, hogy a bíróság korlátlanul enyhítheti azon elkövető büntetését, aki az uzsora-bűncselekményt, mielőtt az a hatóság tudomására jutna, a hatóságnak bejelenti.

A regisztrált uzsora-bűncselekmények száma 2013-tól kezdődően ismét csökkenésnek indult, az alapvető jogok biztosa ugyanis 2013-ban felszólította a kormányt, hogy hozzon létre komplex kríziskezelő szolgáltatást (Alapvető Jogok Biztosának Hivatala 2013). ${ }^{13}$ Ugyanakkor a javulás részben statisztikai jellegü, és az uzsora újabb, kevésbé egyértelmű formáinak megjelenésére vezethető vissza (például az élelmiszer-uzsora, lásd Béres 2015).

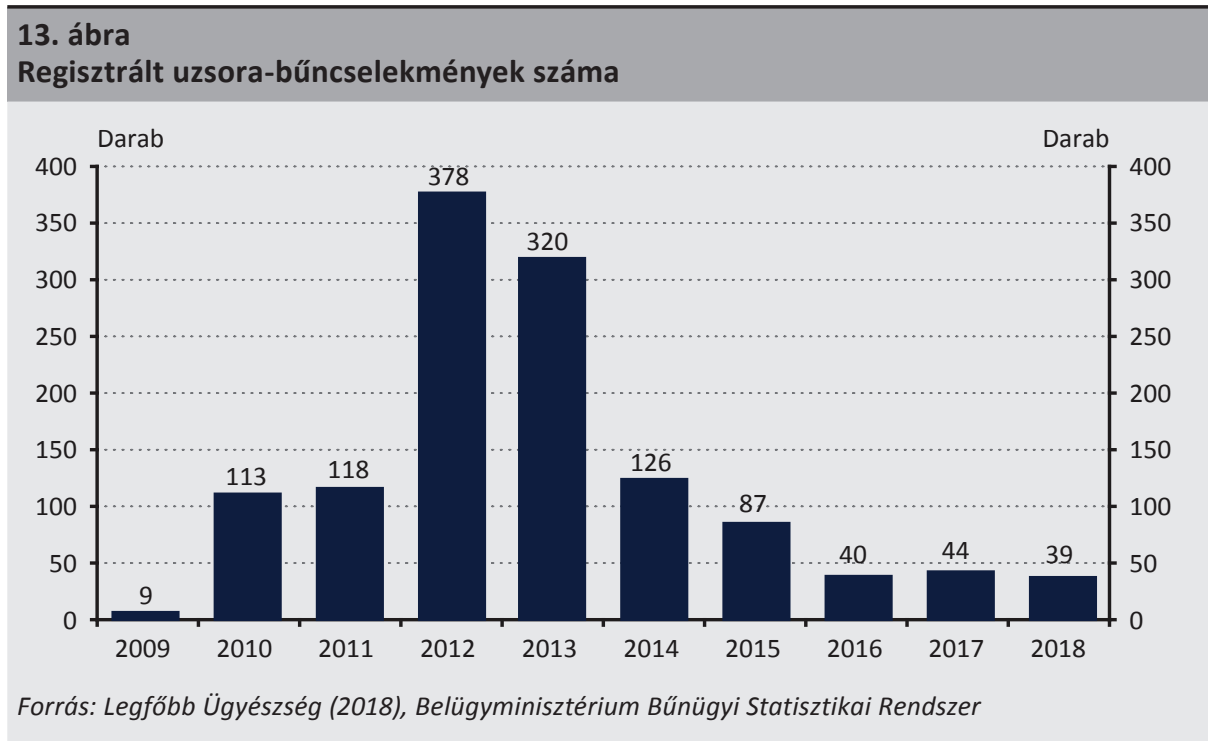

13 „A jelenlegi gyakorlat szerint az áldozatsegítés magában foglalja az áldozat érdekeinek érvényesítését, azonnali pénzügyi segély nyújtását, illetve a jogi segítséget. Általános tapasztalat azonban, hogy az uzsora áldozatai a szigorú törvényi szabályok miatt sem azonnali pénzügyi segélyben, sem kárenyhítésben nem részesülhetnek, számukra jellemzően tájékoztatás formájában tud segítséget nyújtani a szolgálat. Az áldozatsegítés hatékonyságának növelése érdekében ezért a biztos javaslatot tett arra, hogy a közigazgatási és igazságügyi miniszter a belügyminiszterrel és az emberi erőforrások miniszterével együttmúködve kezdeményezze az uzsora-büncselekmények áldozatait komplex módon segítő kríziskezelő szolgáltatás létrehozását (...)" (Alapvető Jogok Biztosának Hivatala 2013:63. o.). 
Annak érdekében, hogy validáljuk eredményeinket, összevetettük a regisztrált uzsora-büncselekmények regionális eloszlását a saját kutatásunk alapján feltárt, potenciális érintettségre vonatkozó területi eloszlással (3. táblázat). A bejelentett bűncselekmények eloszlása hasonló képet mutat az általunk feltártakkal. A hivatalosan regisztrált adatok alapján eredményeinkhez hasonlóan Borsod-Abaúj-Zemplén és Szabolcs-Szatmár-Bereg megyékben látszik a legnagyobb érintettség: a 2013-2018 között regisztrált uzsora-búncselekmények 28 százaléka előbbi, 19 százaléka pedig utóbbi megyében történt, míg az általunk azonosított 64 település 53 százaléka található Borsod, és 17 százaléka Szabolcs megyében. Kutatásunkban mi ugyanakkor 10 zalai települést is uzsorának kitettként azonosítottunk, a hivatalos bűnügyi statisztikában azonban nem látszik a megyei érintettség. Ezzel ellentétben Jász-Nagykun-Szolnok a bünügyi statisztikák alapján a harmadik legjelentősebb mértékben érintett megye, míg kutatásunk alapján a legalacsonyabb hitelpenetrációval és legjelentősebb gazdasági-lakhatási elmaradottsággal jellemezhető, potenciálisan érintett települések egyike sem ebben a megyében található. A negyedik helyen Hajdú-Bihar megye áll, mely szintén összhangban van a településszintű eredményeinkkel, így Jász-Nagykun-Szolnok megye kimaradásában feltehetően a településszintű elmaradottsági adatok elavultsága áll.

\begin{tabular}{|c|c|c|}
\hline \multicolumn{3}{|c|}{ nények száma és megoszlása megyei bontásban } \\
\hline Megye & $\begin{array}{c}\text { 2013-2018 között regisztrált } \\
\text { uzsora-búncselekmények száma } \\
\text { összesen }\end{array}$ & $\begin{array}{c}\text { 2013-2018 között regisztrált } \\
\text { uzsora-búncselekmények } \\
\text { megoszlása (\%) }\end{array}$ \\
\hline Borsod-Abaúj-Zemplén & 183 & 27,9 \\
\hline Szabolcs-Szatmár-Bereg & 122 & 18,6 \\
\hline Jász-Nagykun-Szolnok & 66 & 10,1 \\
\hline Hajdú-Bihar & 64 & 9,8 \\
\hline Nógrád & 50 & 7,6 \\
\hline Pest & 37 & 5,6 \\
\hline Bács-Kiskun & 26 & 4,0 \\
\hline Budapest & 22 & 3,4 \\
\hline Heves & 21 & 3,2 \\
\hline Békés & 19 & 2,9 \\
\hline Somogy & 18 & 2,7 \\
\hline Komárom-Esztergom & 8 & 1,2 \\
\hline Csongrád & 6 & 0,9 \\
\hline Baranya & 5 & 0,8 \\
\hline Veszprém & 4 & 0,6 \\
\hline Fejér & 3 & 0,5 \\
\hline Vas & 2 & 0,3 \\
\hline Győr-Moson-Sopron & 0 & 0,0 \\
\hline Tolna & 0 & 0,0 \\
\hline Zala & 0 & 0,0 \\
\hline
\end{tabular}




\section{Következtetések}

Összességében, eredményeink alapján egy becslési sávot meghatározva 3-13 százalék közé becsüljük a sérülékeny háztartások arányát. Ez azt jelenti, hogy becslésünk szerint Magyarországon a - 2016-os adatok szerinti - 4 millió háztartásból 113 ezer és 523 ezer közé tehető azon háztartások száma, amelyek sérülékenységüknél fogva ki lehetnek téve az informális pénzügyi közvetítésnek, és potenciális keresletet támaszthatnak az ilyen jellegű pénzügyi szolgáltatások iránt. Közvetlen adatok hiányában azonban az uzsorakölcsönzés kiterjedtségét nehéz mérni, így az általunk készített elemzés a probléma lehetséges nagyságrendjét térképezte fel.

A települési és járási szintủ adatok alapján arra is készítettünk becslést, hogy mely településeken lehet elterjedt az uzsorakölcsönzés. Eredményeink azt mutatják, hogy Borsod-Abaúj-Zemplén, Szabolcs-Szatmár-Bereg és Hajdú-Bihar megyék országhatárhoz közeli települései lehetnek érintettek. Ezen területek érintettsége egybecseng a bűnügyi statisztikák megyei bontású listájával.

Az uzsorahitelezés részletesebb kutatását számos tényező nehezíti. Adminisztratív adatgyújtés a rejtett jellege miatt definíció szerint nem valósul meg, a tartozások a hitelezőknél „kockás füzetben” vannak vezetve. A szakirodalom által jelzett területi koncentráció, a kölcsönzési tevékenység illegalitása, valamint a követeléskezelési stratégiaként alkalmazott megfélemlítés miatt a kérdőíves kvantitatív felmérések sem adhatnak valós képet az uzsorahitelezés hazai szerepéról. A szakirodalomban fellelhető kutatások kvalitatív módszertani eszközöket használnak: interjúkkal, fókuszcsoportokkal, részvételi akciókutatással térképezik fel adott településen a pénzkezelés és forrásbevonás módjait.

Hosszabb távon az informális hitelezésnek kitett háztartás hiteligényét a banki hitelpiac nem tudja kielégíteni; ezt sem a prudenciális szabályozás, sem az üzleti modell nem teszi lehetővé. Az uzsorahitelezés felszámolását célzó intézkedések előtt a szabályozónak az érintettek körülményeit és motivációit helyszíni kutatásokkal szükséges feltérképeznie, mivel az uzsora jogi eszközökkel történő, fokozottabb visszaszorítása önmagában nem oldja meg az azt igénybe vevők forrásigényét. Tekintettel arra, hogy a népesség e köre több szempontból is sérülékenynek tekinthetö, a probléma felszámolását célzó szakpolitikai lépéseknek a célzott területi és lakhatási támogatások éppúgy részét kell, hogy képezzék, mint a pénzügyi szolgáltatásokhoz való hozzáférés elősegítése elsősorban digitális csatornákon keresztül, valamint a pénzügyi edukáció. 


\section{Felhasznált irodalom}

Alapvető Jogok Biztosának Hivatala (2013): A válság vesztesei - a paragrafusok fogságában projekt. AJB Projektfüzetek.

Béres Tibor (2015): Az élelmiszer-uzsoráról. Esély, 2015(5): 93-102.

Béres Tibor - Lukács György (2008): Kamatos pénz a Csereháton. Esély, 2008(5): 71-97.

Collins, D. - Morduch, J. - Rutherford, S. - Ruthven, O. (2009): Portfolios of the Poor: How the World's Poor Live on \$2 a Day. Princeton, University Press.

Durst Judit (2017): „De ugye biztos nem lesz ebből baj?” Módszertani reflexiók az informális gazdaságot övező félelem csendjének megtöréséröl. 2000, 29(5): 61-78.

Gosztonyi Márton (2018): A pénz zsonglörei. Az alacsony jövedelmü családok pénzügyi túlélési stratégiája és egy részvételi akciókutatás története. Budapesti Corvinus Egyetem, Szociológiai Doktori Iskola. PhD-értekezés.

Hüse Lajos - Fábián Gergely - Szoboszlai Katalin (2008): „Van itten elég sok szegénység...” Az uzsorakamat intézményének empirikus kutatása. Kapocs, 7(2).

KSH (2017): A háztartások életszínvonala. 2016. Központi Statisztikai Hivatal, Budapest. https://www.ksh.hu/docs/hun/xftp/idoszaki/hazteletszinv/hazteletszinv16.pdf

KSH (2018): Digitális gazdaság és társadalom, 2018. Központi Statisztikai Hivatal, Budapest. https://www.ksh.hu/docs/hun/xftp/idoszaki/ikt/ikt18.pdf

KSH (2019): A háztartások életszínvonala, 2018. Központi Statisztikai Hivatal, Budapest. https://www.ksh.hu/docs/hun/xftp/idoszaki/hazteletszinv/2018/index.html

Legfőbb Ügyészség (2018): Tájékoztató a 2017. évi bünözésröl. http://ugyeszseg.hu/pdf/ statisztika/Tajekoztat\%C3\%B3_a_2017_evi_bunozesrol.pdf

Messing Vera (2006): Lyukakból szőtt háló. Háztartások közötti támogató kapcsolatok roma és nem roma szegények körében. Szociológiai Szemle, 2006(2): 37-54.

Messing Vera - Molnár Emília (2011): Válaszok a pénztelenségre: szegény cigány és nem cigány családok megélhetési stratégiái. Esély, 2011(1), 53-80. 


\section{Mellékletek}

\section{1. melléklet: Az adósságfék-szabályok alakulása Magyarországon}

A háztartások túlzott eladósodásából fakadó kockázatok mérséklése érdekében a Magyar Nemzeti Bank 2015. január 1. napjával hatályba lépett 32/2014. (IX. 10.) rendelete (adósságfék-rendelet) maximálta a pénzügyi közvetítők lakossági hitelnyújtásában a jövedelemarányos törlesztőrészlet (JTM) és a hitelfedezeti mutató (HFM) nagyságát.

Az adósságfék-szabályokat magánszemélyek részére - nem üzleti céllal - igényelt hitel, kölcsön és lízingszerződésből eredő tartozás törlesztőrészleteinek meghatározásakor kell alkalmazni. A JTM az ügyfelek rendszeres jövedelmének meghatározott arányában maximálja az új hitelfelvételkor vállalható törlesztési terheket, ezáltal mérsékli az ügyfelek eladósodását. Számításakor a havi törlesztőrészlet összegét kell elosztani az igazolt havi nettó jövedelem összegével. Adóstársak esetében az igazolt havi nettó jövedelmek összeadhatók. A HFM a fedezett hiteleknél (pl. jelzáloghitelek) a fedezetek (lakásérték) arányában korlátozza a felvehető hitel maximális összegét.

A hazai JTM- és HFM-előírások szintjei

\begin{tabular}{|c|c|c|c|c|}
\hline & & HUF & EUR & Egyéb deviza \\
\hline \multirow{2}{*}{$\underset{上}{\Sigma}$} & 400 ezer Ft alatti havi nettó jövedelem & $50 \%$ & $25 \%$ & $10 \%$ \\
\hline & 400 ezer Ft vagy afeletti havi nettó jövedelem & $60 \%$ & $30 \%$ & $15 \%$ \\
\hline \multirow{2}{*}{$\underset{\text { 㞱 }}{\sum_{2}}$} & Jelzáloghitelre & $80 \%$ & $50 \%$ & $35 \%$ \\
\hline & Gépjármúhitelre & $75 \%$ & $45 \%$ & $30 \%$ \\
\hline
\end{tabular}

Megjegyzés: 2015. január 1. és 2018. október 1. között hatályos.

Forrás: $M N B$

Az MNB a hosszabb kamatperiódus mellett nyújtott jelzáloghitelek ösztönzése érdekében 2018. október 1-jével a 29/2018. (VIII. 21.) MNB rendelet által módosította az adósságfék-szabályokat. Az új szabályozás értelmében kamatperiódus szerint differenciált jövedelemarányos törlesztőrészletek kerültek meghatározásra.

\section{A jövedelemarányos törlesztőrészlet-mutató értékei kamatperiódus szerint}

\begin{tabular}{l|c|c|c}
\hline \multicolumn{1}{|c|}{ Havi nettó jövedelem } & Kevesebb, mint 5 év & $\begin{array}{c}\text { Legalább 5 év, de } \\
\text { kevesebb, mint 10 év }\end{array}$ & $\begin{array}{c}\text { Legalább 10 év vagy } \\
\text { végig fix }\end{array}$ \\
\hline $\begin{array}{l}400 \text { ezer Ft } \\
\text { (2019. július 1-től } 500 \text { ezer Ft) } \\
\text { alatti }\end{array}$ & $25 \%$ & $35 \%$ & $50 \%$ \\
\hline $\begin{array}{l}400 \text { ezer Ft } \\
\text { (2019. július 1-től } 500 \text { ezer Ft) } \\
\text { vagy feletti }\end{array}$ & $30 \%$ & $40 \%$ & $60 \%$ \\
\hline
\end{tabular}

Megjegyzés: 2018. október 1-töl hatályos.

Forrás: $M N B$ 
A magasabb jövedelemmel rendelkezők - nagyobb adósságtörlesztési képességük miatt - továbbra is magasabb havi törlesztés mellett vehetnek fel hitelt. A bérek emelkedésére is tekintettel a magasabb arányú törlesztőrészletek vállalását a rendelet 2019. július 1-től már 500 ezer forint havi nettó jövedelem estén teszi lehetővé [24/2019. (VI. 26.) MNB rendelet].

\section{2. melléklet: Az alacsony hitelpenetrációjú járások megyénként}

\begin{tabular}{l|l}
\hline Bács-Kiskun & Győr-Moson-Sopron \\
Bácsalmás & Csorna \\
Baja & Kapuvár \\
Kalocsa & Mosonmagyaróvár \\
Kiskörös & Sopron \\
\cline { 2 - 2 } Kiskunmajsa & Hajdú-Bihar \\
\hline Baranya & Derecske \\
Pécsvárad & Nyíradony \\
\hline Borsod-Abaúj-Zemplén & Heves \\
Edelény & Bélapátfalva \\
\cline { 2 - 2 } Gönc & Nógrád \\
Mezökövesd & Balassagyarmat \\
Sárospatak & Szabolcs-Szatmár-Bereg \\
Tokaj & Csenger \\
\hline Csongrád & Nyírbátor \\
\cline { 2 - 2 } Kistelek & Zala \\
Mórahalom & Keszthely \\
& Lenti \\
\hline Forrás: MNB & Letenye \\
\hline
\end{tabular}

